\title{
๑ LIMITES LEGAIS ÀS EXPERIMENTAÇÕES COM EMBRIÕES HUMANOS
}

\author{
LEGAL LIMITS TO THE EXPERIMENTATION WITH HUMAN EMBRYOS
}

LIMITES LEGALES AUX EXPÉRIMENTATIONS AVEC EMBRYONS HUMAINS

\author{
Erickson Gavazza Marques \\ Professor Emérito da Universidade Nove de Julho (Uninove) \\ Desembargador do Tribunal de Justiça de São Paulo \\ Doutor em Ciências pelo Instituto de Ciências Biomédicas da USP \\ Especialização em Bioética pela Faculdade de Medicina da USP \\ ericksonmarques@uni9.pro.br
}

\begin{abstract}
Resumo: O uso de embriões em pesquisa científica, no Brasil, nos últimos tempos, possibilitou que fosse dado, a esse objeto de estudo, uma destinação mais nobre do que o simples descarte. Uma vez superada toda controvérsia em torno da possibilidade, ou não, da utilização de embriões em pesquisas com células-tronco, o que se percebe é que o Brasil, que inicialmente possuía uma legislação restritiva, passou a ser dotado de leis mais favoráveis. Dentre tais normas temos as Resoluções do CNS 196/96 e do CFM 2.294/2021, bem como a Lei $\mathrm{n}^{\circ}$ $11.105 / 2005$ e o Decreto $n^{0} 5.5591 / 2005$, sendo que, no exterior, a tendência de se impor regras restritivas a essas experiências está amparada pelas mesmas motivações éticas que inspirou o surgimento de várias legislações surgidas após o último grande conflito mundial, tais como na França e na Espanha.
\end{abstract}

Palavras-chave: experimentos com embriões; células-tronco embrionárias; Lei de Biossegurança.

Abstract: The use of embryos in scientific research in Brazil in recent times has made it possible for this object of study to be given a nobler destination than simple disposal. Once all controversy over the possibility or not of using embryos in stem cell research has been overcome, what can be seen is that Brazil, which initially had restrictive legislation, became endowed with more favorable laws. Among such norms we have CNS Resolutions 196/96 and CFM 2.294/2021, as well as Law $n^{\circ} 11.105 / 2005$ and Decree $n^{\circ} 5.5591 / 2005$, and abroad, the tendency to impose restrictive rules on these experiences this is supported by the same ethical motivations that inspired the emergence of various legislations that emerged after the last great world conflict, such as in France and Spain.

Keywords: experiments with embryos; embryonic stem cells; Biosafety Law.

Resumé: L'utilisation d'embryons dans la recherche scientifique au Brésil ces derniers temps a permis de donner à cet objet d'étude une destination plus noble que la simple élimination. Une fois toutes les controverses sur la possibilité ou non d'utiliser des embryons dans la recherche sur les cellules souches surmontées, on constate que le Brésil, qui avait initialement une législation restrictive, s'est doté de lois plus favorables. Parmi ces normes, nous avons les résolutions CNS 196/96 et CFM 2.294/2021, ainsi que la loi $\mathrm{n}^{\circ} 11.105 / 2005$ et le décret $\mathrm{n}^{\circ}$ 
5.5591/2005, et à l'étranger, la tendance à imposer des règles restrictives sur ces expériences est soutenue par la même éthique. motivations qui ont inspiré l'émergence de diverses législations qui ont émergé après le dernier grand conflit mondial, comme en France et en Espagne.

Mots-clés: expériences avec embryons; cellules-souches embryonnaires; Loi de Biosécurité.

Para citar este artigo (ABNT NBR 6023:2018)

MARQUES, Erickson Gavazza. Limites legais às experimentações com embriões humanos. Revista Thesis Juris - RTJ, São Paulo, v. 10, n. 2, p. 357-374, jul./dez. 2021.

http://doi.org/10.5585/rtj.v10i2.20999.

\section{Introdução}

Há pouco mais de quarenta e três anos um feito inédito de cientistas britânicos tornou possível a concepção de um ser humano fora do corpo da mulher através do emprego de uma técnica chamada de fertilização “in vitro” (FIV), espécie do gênero reprodução humana assistida $^{1}$. Isso ocorreu precisamente no dia 5 de julho de 1978, nas dependências da maternidade do Hospital Oldham, em Londres, na Grã-Bretanha. Na ocasião, veio ao mundo um bebê do sexo feminino, registrado sob o nome de Louise Joy Brown: nasce o primeiro bebê de proveta de que se tem notícia.

Essa façanha foi obra dos britânicos Patrick Steptoe e Robert Edwards. Os dois selecionaram o casal Brown, que há doze anos esperava a oportunidade para ter filhos. A causa da infertilidade ${ }^{2}$, relativamente frequente nos casais, estava no fato de que a Senhora Brown tinha as trompas obstruídas.

\footnotetext{
${ }^{1}$ São duas as técnicas de reprodução humana assistida: a inseminação artificial, que consiste em depositar sêmen no interior do aparelho reprodutor da mulher para que lá os espermatozóides contidos no líquido seminal possam partir para fecundação dos óvulos já maduros; e a fertilização in vitro, que significa proceder à fecundação de forma extracorpórea, in vitro, transferindo-se posteriormente, para o interior do organismo da mulher, o resultado dessa fecundação, no caso um embrião.

${ }^{2}$ Considerada como sendo a impossibilidade de procriar após mais de um ano de tentativas, a infertilidade pode ter, tanto no homem quanto na mulher, origens das mais diversas.

Sem pretender enumerá-las exaustivamente, a infertilidade, no homem, ela pode ter como causas principais fatores ligados a qualidade ou a quantidade de gametas. Tal é o caso, por exemplo, da presença de um baixo número deles no liquido seminal, o que representa uma taxa inferior a 20 milhões de espermatozóides por um mililitro de sêmen, ou ainda a produção de gametas com uma morfologia imprópria, pois o formato inadequado pode dificultar a perfuração no óvulo. Outro aspecto que contribui para a infertilidade masculina é o fato dos espermatozoides produzidos não se revestirem de mobilidade suficiente para chegar até o óvulo. Enfim, ainda no elenco das causas de infertilidade no homem temos a ejaculação incipiente e a dificuldade de ereção.

Nas mulheres as causas de infertilidade estão frequentemente ligadas, dentre outros motivos, a distúrbios hormonais, como por exemplo anomalias na formação de estrogênio, hormônio que controla a produção do muco cervical que facilitará a penetração dos espermatozoides no colo do útero, ou, ainda, a endometriose, que é a
} 
Em razão de tal fato o Dr. Steptoe realizou uma punção no organismo da Sra. Brown retirando, cirurgicamente, através de laparoscopia, alguns óvulos não fertilizados da paciente. Esses mesmos óvulos foram fertilizados, quer dizer fecundados ${ }^{3}$, com o esperma do Senhor Brown e transportados para um recipiente - proveta - onde, com temperatura e meio de cultura cuidadosamente controlados, após a fusão dos núcleos e algumas divisões celulares ${ }^{4}$, o óvulo tornou-se uma massa de células ${ }^{5}$ que, por sua vez, originou um embrião ${ }^{6}$. Após tratamento hormonal, o embrião foi introduzido no útero da Sra. Brown, local onde se desenvolveu até o momento da concepção.

Não obstante as críticas severas feitas aos trabalhos de Steptoe e Edwards, o procedimento de fertilização in vitro proliferou-se no mundo inteiro. No Brasil, o nascimento do primeiro bebê por técnicas de fertilização in vitro, Ana Paula Caldeira, aconteceu em meados dos anos 80, mais precisamente em 7 de outubro de 1984, em São José dos Pinhais, no Paraná.

Com o desenvolvimento desta técnica, ocasionado em grande parte pela propagação de suas práticas, percebeu-se que a possibilidade de sucesso da gravidez nos casos de fertilização in vitro dependeria, dentre outros fatores, da quantidade de embriões transferidos para o útero, pois quanto maior o número deles, nessa condição, maior seria a possibilidade de êxito. E foi a partir daí que os médicos especialistas em reprodução assistida passaram a introduzir, no útero da futura gestante, mais de um óvulo ao mesmo tempo.

Isso resultou no aumento dos riscos de gravidez múltipla ${ }^{7}$. O que provocou a necessidade de se limitar a transferência, para o útero materno, dos óvulos fecundados, já na fase a que se pode chamar de embrião. Hoje, conforme a recém-nascida Resolução $n^{\circ} 2.294$, de 27/05/2021, do Conselho Federal de Medicina, recomenda-se a implantação de dois a três

produção de quantidade excessiva de mucosa que recobre as paredes do útero, o que dificulta a nidação. Também contribuem para a infertilidade na mulher os problemas relacionados aos ovários, tais como a síndrome de ovários policísticos, a falta ou a insuficiência de ovulação, ou, enfim, a não liberação do óvulo para fecundação. Além disso, pode haver obstrução das trompas, o que impossibilita a fixação do óvulo expulso do ovário.

${ }^{3}$ Fecundação é o ato através do qual há penetração, vale dizer perfuração, do óvulo pelo espermatozoide, e não um simples encontro de gametas, como equivocadamente se diz.

${ }^{4}$ São necessárias em torno de 24 horas para a primeira divisão celular.

${ }^{5}$ Depois de sucessivas divisões celulares, mais precisamente no $4^{\circ}$ dia, o óvulo fecundado atinge o tamanho de aproximadamente 32 células, momento em que é conhecido pelo nome de mórula.

${ }^{6}$ Isso ocorre em torno do $6^{\circ}$ dia após a fecundação.

${ }^{7}$ A gravidez múltipla consiste na gestação de mais de um embrião, ou feto, no interior do mesmo organismo feminino e ao mesmo tempo, culminando no nascimento de mais de um bebê no mesmo parto. Esse tipo de gravidez, que teve um aumento considerável graças a expansão dos métodos de fertilização in vitro, pode ter sérias conseqüências para a gravidez, tais como o nascimento de recém-nascidos prematuros e de baixo peso, além de implicações respiratórias e neurológicas. Isso porque em um espaço originariamente destinado ao "habitat" de um feto, na gravidez múltipla esse mesmo "universo" passaria a ser sendo dividido por vários fetos ao mesmo tempo, o que acarreta a necessidade de ser partilhado tudo aquilo que a gestante fornece biologicamente para o desenvolvimento do seu bebê, com a conseqüente diminuição do quinhão de cada um. E quanto maior o número de bebês em gestação, maior é a possibilidade de problemas. 
embriões, dentre aqueles considerados viáveis para efeito de implantação no útero da mulher. Os óvulos fecundados restantes, que não foram passíveis de implantação no útero, ou porque não estavam aptos para sê-lo ou por ultrapassar o número aconselhado para implantação, são conhecidos como óvulos ou embriões excedentes.

O desenvolvimento e aprimoramento dessas técnicas resultaram na aparição de uma figura até então desconhecida: a dos embriões excedentes. Estes podem ser definidos como sendo o produto da fusão dos gametas, masculino e feminino, mantidos em estado de conservação in vitro, e que não serão objeto de implantação no útero da mulher em procedimentos de fertilização assistida.

Assim, se não são mais aptos para utilização em processos de fertilização assistida, qual seria a destinação destes embriões excedentes? Os óvulos restantes, já fecundados, poderão ter um dos destinos a seguir descritos: 1) ser simplesmente descartados, ou 2) congelados para uso posterior em determinados tipos de pesquisas científicas, "verbi gratia" com células-tronco. Essas células podem ser encontradas no embrião, ocasião em que são chamadas de célulastronco embrionárias, ou no feto, no sangue do cordão umbilical ou, ainda, em certos órgãos de um indivíduo adulto, como por exemplo, na polpa dos dentes. Nessas últimas três situações estamos diante de células-tronco adultas. A diferença entre as células-tronco adultas e as células-tronco embrionárias é que aquelas poderão originar alguns tipos de células apenas, sendo, por esta razão, classificadas em plenipotentes, semipotentes etc. Já as células-tronco embrionárias poderão dar origem a quase todos os tipos de células existentes no organismo, à exceção daquelas que formarão a placenta, a respectiva membrana e o líquido amniótico. São, por isso, classificadas como totipotentes. Daí a sua importância para a pesquisa científica.

Ocorre que, de um passado não muito distante, nos chegam relatos estarrecedores de experimentação com embriões, feitas dos piores modos possíveis, em total desrespeito à pessoa humana, ofendendo frontalmente as mais elementares regras de boa civilidade. Operou-se, logo em seguida ao período mais sombrio destas experiências, uma tentativa de regulamentação internacional para a matéria, o chamado Código de Nuremberg de 1947. Desse momento em diante, não cessaram as tentativas de se chegar a uma regulamentação ideal, em que os embriões fossem empregados com respeito à dignidade humana.

A regulamentação internacional para a prática de experimentação em seres humanos, inclusive embriões, parece ter como marco inicial o final das hostilidades por ocasião da Segunda Guerra Mundial. Mais precisamente em 9 de dezembro de 1946, quando um grupo de 
médicos alemães foi levado a julgamento perante um tribunal internacional instituído na cidade de Nuremberg ${ }^{8}$.

Esse processo, que não se confunde com o mais famoso a que foram submetidos os principais líderes da Alemanha nazista, é mais conhecido como "o processo dos médicos", e envolveu 20 médicos e 3 cientistas, tendo sido o primeiro dos 12 instituídos dentro da zona de influência americana em Berlim. A ele seguiram-se vários outros envolvendo juízes, militares e dirigentes do antigo III Reich alemão, com o intuito de apurar e julgar as atrocidades e os crimes cometidos durante a guerra ${ }^{9}$.

No caso do processo dos médicos, que é o que nos interessa, os horrores foram praticados dentro do contexto de experimentações médico-científicas desenvolvidas entre 1933 e 1945, período em que Adolph Hitler esteve à frente da Alemanha. Durante os depoimentos ${ }^{10}$ prestados perante aquela Corte de Nuremberg, o mundo tomou conhecimento dos absurdos supostamente cometidos em nome da ciência. Esses médicos e pesquisadores realizavam experimentos científicos durante o regime nazista fazendo de cobaias muitos prisioneiros recolhidos nos campos de concentração, contra a própria vontade desses sujeitos da pesquisa e, na maioria das vezes, causando, nos mesmos, lesões corporais de natureza grave, homicídios e até verdadeiras carnificinas. E tudo isso sob o falso rótulo de pesquisa científica.

Esse cenário gerou uma ampla conscientização no sentido de que se fazia absolutamente necessário estabelecer um marco legal para a experimentação em seres humanos. Desde o início e durante o desenrolar da instrução do "processo dos médicos", os Juízes Walter BurgesBeals, Harold Leon Sebring, Johnson Grawford e Victor Clearence Swearingen perceberam que ali não se tratava apenas de sentenciar alguns médicos e cientistas nazistas pela suposta prática de crimes contra a humanidade, mas também de estabelecer limites não só legais, mas antes de tudo éticos, para a pesquisa e experimentação biomédica ${ }^{11}$. Daí o surgimento, nesse período, de

\footnotetext{
${ }^{8}$ Segundo HALIOUA, a cidade de Nuremberg foi escolhida como sede do tribunal, por proposta de Robert Jackson, Juiz daSuprema Corte Norte-Americana e que, no Tribunal Militar Internacional, atuaria como membro da Promotoria, em razão de existir uma prisão nas proximidades do Palácio da Justiça, e cujo prédio possui 22 mil metros quadrados, 530 gabinetes de trabalho e 80 salas de audiência e, enfim, ter sido pouco bombardeada durante a guerra ("Du procès au Code de Nuremberg: principès de l'éthique biomédicale", par Bruno Halioua, in Traité de Bioéthique, ÉditionsÉrès, Toulouse, 2010, tome I , p. 236, nota n ${ }^{\circ} 1$ ).

${ }^{9}$ HALIOUA, Bruno, Du procès au Code de Nuremberg: principes de l'éthique biomédicale, Traité de Bioétique, I, Fondements, príncipes, repéres, org. Emmanuel Hirsch, Ed. Érès, 2010, p. 236

${ }^{10}$ Conforme nos relata HALIOUA, durante a instrução foram ouvidas 32 testemunhas de acusação e 53 de defesa, além de terem sido examinados 1471 documentos (Bruno Haliou, Du procès au Code de Nuremberg: principès de l'éthique biomédicale", in Traité de Bioéthique, Éditions Érès, Toulouse, 2010, tome I, p. 238).

${ }^{11}$ HALIOUA, Bruno, Du procès au Code de Nuremberg: principes de l'éthique biomédicale, in Traité de Bioétique, I, Fondements, príncipes, repéres, org. Emmanuel Hirsch, ed. Érès, 2010, p. 236

${ }^{11}$ Idem, p. 238.
} 
uma codificação destinada a servir de guia universal para a regulamentação deste tipo de pesquisa, o chamado Código de Nuremberg ${ }^{12}$.

Para se ter uma ideia do trauma causado pelas práticas nazistas, e de como a questão do consentimento para a experimentação passou a ser encarada, basta lembrar que o Código de Nuremberg, em sua primeira edição, simplesmente proibia a realização de experimentos sobre indivíduos cuja capacidade de consentir estava comprometida, o que foi objeto de atenuação com a modificação feita no Código por ocasião da revisão feita na Declaração de Helsinki, onde estabeleceu-se que a incapacidade de consentir poderia ser substituída pela manifestação de um representante legal do futuro sujeito da pesquisa. ${ }^{13}$

Ainda que os Estados Unidos da América entendam que a Declaração de Helsinki, na sua revisão datada de outubro de 2008, seja demasiadamente favorável ao sujeito da pesquisa, em detrimento da experimentação ${ }^{14}$, o fato é que o Código de Nuremberg continua sendo uma referência internacional em matéria de regulamentação da pesquisa científica, sendo reconhecido por quase todos os países como um parâmetro legislativo a respeito.

Daí porque se tornou absolutamente necessário, inclusive por questões de saúde pública, o estabelecimento de princípios éticos de modo a estabelecer limites à realização e experimentos científicos desta natureza.

Todavia, sabemos que esses princípios éticos possuem eficácia restrita, o que significa dizer que se eles não forem transformados em normas de direito positivo, muito pouco se poderá obter de resultados práticos quanto a coibir-se abusos no tocante à experimentação com embriões humanos. Assim, veremos que tanto no Brasil (II) quanto no exterior (III) operou-se a positivação dos princípios éticos que passaram a ser exigidos das pesquisas com seres humanos, inclusive embriões.

\footnotetext{
${ }^{12}$ O Código de Nuremberg é um conjunto de regras de caráter extra-legal, eis que não são leis em sentido estrito, podendo ser compreendidas dentro do que conhecemos hoje por soft law. São preceitos de ordem ética destinados a orientar os profissionais ligados às ciências da vida na condução de suas práticas profissionais cotidianas, de modo a fazê-lo observando-se a praxe da moral do respectivo ofício. Recebeu esse nome em razão da cidade onde veio à público a ocorrência de vários fatos que revelaram a urgência da elaboração de um conjunto de regras de conduta no campo da experimentação científica. Trata-se do tribunal de Nuremberg, local onde foram julgados 20 homens pertencentes ao alto comando do III Reich. Destes, três foram absolvidos, doze foram condenados à morte por enforcamento, e sete foram enviados à prisão para cumprimentos de penas das variadas (SMITH, Bradley F., O Tribunal de Nuremberg, tradução de Henrique de Araújo Mesquita, Livraria Francisco Alves Editora S.A., RJ, 1979, p. XIII).

${ }^{13}$ Weisstub, David, Arboleda-Florez, Julio e Tomossy, George, La Recherche sur des populations vulnérables, Les Populations Vulnérables, éd. L’Harmattan, 2001, p.6.

${ }^{14}$ Sicard, Didier, L’Ethique Médicale et la Bioéthique, éd. Press Universitaires de France, 2009, p. 50
} 


\section{Desenvolvimento}

\section{Limitações aos experimentos com embriões na legislação brasileira}

No Brasil, as limitações impostas à experimentação com embriões estão revestidas na forma de regras de caráter ético, portanto não tem natureza erga omnes, tal como é o caso das Resoluções CNS 340/04 e 466/12 e CFM 2.294/2021 (A), bem como em leis em sentido amplo, verbi gratia a Lei ${ }^{\circ} 11.105 / 2005$ e o Decreto $\mathrm{n}^{\circ} 5.5591 / 2005$ (B).

\section{a. Limites oriundos de normas do Conselho Nacional de Saúde (CNS) e do Conselho Federal de Medicina $(C F M)$}

Por força da Resolução CNS n 466/12, os Comitês de Ética em Pesquisa (CEP) envolvidos em projetos de experimentos com seres humanos, inclusive embriões, obrigam-se a avaliar os protocolos de pesquisa, fazendo-o "com base nos indicadores epidemiológicos, emitindo parecer, devidamente justificado e sempre orientado pelos princípios da impessoalidade, transparência, razoabilidade, proporcionalidade e eficiência, dentro dos prazos estabelecidos em norma operacional, evitando redundâncias que resultem em morosidade na análise" ${ }^{\prime 15}$.

O caráter restritivo desta exigência justifica-se pelo fato do projeto originário de pesquisa já ter sido objeto de análise prévia e aprovação pelo Comitê de Ética em Pesquisa da instituição responsável pela pesquisa, sendo que qualquer desvio ou alteração em sua consecução não terá sido objeto do mesmo tipo de monitoramento social, o que pode ser prejudicial, já que os Comitês de Ética têm por principal finalidade, mais do que impulsionar o desenvolvimento da ciência, evitar que possíveis danos possam ocorrer por conta do implemento da pesquisa, prejudicando a saúde pública e até o meio ambiente. O que não seria impossível de imaginar-se caso ocorresse um acidente biológico envolvendo o experimento.

Do mesmo modo que a Resolução CNS no 466/21, a Resolução CNS no 340/04, que trata especificamente de projeto de pesquisa na área de genética, no seu item III.12, determina que deva ser seguido o protocolo de pesquisa, sendo necessária a aprovação de um novo documento para o caso de desdobramento dos estudos ${ }^{16}$.

\footnotetext{
${ }^{15}$ Resolução 466/21, VIII.1.

16 “III.12 - Dados genéticos humanos coletados em pesquisa com determinada finalidade só poderão ser utilizados para outros fins se for obtido o consentimento prévio do indivíduo doador ou seu representante legal e mediante a elaboração de novo protocolo de pesquisa, com aprovação do Comitê de Ética em Pesquisa e, se for o caso, da CONEP. Nos casos em que não for possível a obtenção do TCLE, deve ser apresentada justificativa para apreciação pelo CEP."
} 
Em outras palavras, a informação genética obtida em pesquisa científica específica não deverá ser objeto de outra utilização senão aquela inicialmente autorizada pelo seu titular, sendo necessário que o pesquisador obtenha uma nova autorização do titular dos dados genéticos, bem como elabore um novo protocolo de pesquisa, a ser aprovado tanto pelo Comitê de Ética e Pesquisa correspondente, quanto pelo Comitê Nacional de Ética em Pesquisa, conforme o caso ${ }^{17}$.

Assim, na hipótese de não ser possível obter o consentimento do pesquisado, a norma ${ }^{18}$ permite que seja feita a pesquisa, mas desde que satisfeitas algumas condições: 1) a não identificação dos dados genéticos que se pretende usar, 2) apresentação, pelo pesquisador, de uma justificativa declinando as razões pelas quais não logrou êxito em obter o consentimento do pesquisado, 3) aceitação dessa justificativa pelos CEP e CONEP. Uma vez satisfeitas tais condições, o pesquisador poderá fazer uso dos dados genéticos de um indivíduo, mesmo sem o consentimento deste, contrariando as suas próprias normas que afirmam ser aplicáveis aos sujeitos da pesquisa: “[...] autorizar ou não o armazenamento de dados e materiais coletados no âmbito da pesquisa, após informação dos procedimentos definidos na Resolução sobre armazenamento de materiais biológicos [...]"19.

Outra restrição para os experimentos é que devemos estar diante de embriões excedentes produzidos por técnicas de fertilização in vitro, não se podendo falar em experiências com embriões gerados de outra maneira.

Isso porque já há quase um consenso, entre os principais países onde se produzem pesquisas com embriões, no sentido de que estes não devam ser criados especialmente para esse fim. Os embriões destinados a experimentação devem ser aqueles não mais utilizados em outros procedimentos de reprodução assistida.

A Resolução CFM n 2.294/2021 proíbe, por via indireta, a produção de embriões destinados exclusivamente à pesquisa. Essa norma determina que não se pode proceder à "fecundação de ovócitos humanos, com qualquer outra finalidade que não seja a procriação humana", enunciado que está, acertadamente, reproduzido de forma literal no artigo $6^{\circ}$ do PL $1.135 / 03^{20}$. Em outros termos, tudo o que estiver fora do âmbito de reprodução humana não pode servir como justificativa para a produção de embriões.

\footnotetext{
${ }^{17}$ Resolução CNS 340/04, III, 12.

${ }^{18}$ Resolução CNS 340, III.8 combinado com o III.12.

${ }^{19}$ Resolução CNS 340/04, III.6.

${ }^{20}$ O PL 1135, de 2003, de autoria do Deputado Pinotti, “dispõe sobre a reprodução humana assistida". Ele tem como apenso o PL 2855/97.
} 


\section{b. Limites impostos pela legislação de biossegurança}

Sabemos que os embriões destinados à experimentação, na legislação brasileira, são chamados de embriões excedentes. Esses embriões, por não serem os mais aptos a fazer vingar uma gravidez, ficam de fora da transferência, devendo os mesmos ser mantidos em estado de criopreservação. Ora, como a ampla maioria deles nunca será reclamada pelos genitores, não resta outra solução às clínicas de fertilização senão o descarte dos mesmos. Mas, em sendo assim, ao invés de descartá-los, por que não utilizá-los para pesquisa? Foi o que previu a lei brasileira - Lei de Biossegurança - que entrou em vigor em 2005, cuja constitucionalidade foi confirmada pelo Supremo Tribunal Federal na ADIn $3510-^{21}$, de relatoria do Ministro Carlos Ayres Brito, confirmando a permissão, para utilização, dos embriões inviáveis.

Mas a proibição deve incluir, também, não só aqueles viáveis, que são produto de fertilização in vitro, mas todo e qualquer embrião que já esteja no interior do corpo da futura genitora. $\mathrm{O}$ que se pretende, com a extensão da proibição, é impedir a criação de embriões de segunda classe, não destinados a um projeto familiar, e sim para servir exclusivamente de matéria-prima para as pesquisas científicas. Para esse fim, entendemos que bastam os embriões excedentes. Essa orientação, ao que parece, vem sendo seguida pela maior parte das nações civilizadas.

Outra condição é que os genitores desse embrião tenham consentido na utilização do mesmo em experimentos científicos. Essa autorização deve revestir-se de requisitos especiais, tais como o caráter expresso e inequívoco, além de ser manifestada após os esclarecimentos necessários à elucidação, prestados junto a quem dará o consentimento. Nessas explicações, será mencionado o destino dos embriões após a experimentação, com detalhes a respeito de cada procedimento a qual o embrião deva ser submetido, sendo que, ao realizar tais esclarecimentos, o cientista terá que fazê-lo de forma inteligível, de modo que qualquer do povo possa compreender o alcance, a extensão e as consequências do consentimento que está sendo dado.

Em síntese, a principal destinação dada pela Lei de Biossegurança aos embriões é para que deles possam ser extraídas células-tronco para uso em pesquisa ou terapia.

Ocorre que a partir de um determinado momento do desenvolvimento embrionário as células começam a adquirir, cada uma delas, a sua diferenciação, o que parece acontecer após

\footnotetext{
${ }^{21}$ Ação Direta de Inconstitucionalidade nº 3510.
} 
o $7^{\circ}$ dia contado da fecundação ${ }^{22}$. Essa especificidade quer dizer que cada célula tem a capacidade de se diferenciar, de produzir um dos mais de 200 tipos de tecidos distintos, tais como tecido sanguíneo, neurológico, ósseo, dentre outros, o que não acontece com outro tipo de células-tronco, as adultas.

Ora, o objetivo principal destas pesquisas é descobrir como opera o mecanismo da diferenciação celular. Considerando que a programação da célula tanto para quantidade (a divisão celular) quanto qualidade (tipo celular) está nos dados genéticos contidos no DNA, então como alterar essa mensagem de modo a redirecionar a orientação para que a célula se desenvolva para a constituição de determinado tipo de tecido. Esse é o grande desafio da genética nos dias de hoje: reprogramar, através das células-tronco, os dados genéticos contidos no DNA.

Essa modalidade de utilização de embriões para pesquisa só foi possível a partir de 2005. Com efeito, a Lei de Biossegurança passou a autorizar, em seu artigo $5^{\circ}$, "para fins de pesquisa e terapia, a utilização de células-tronco embrionárias obtidas de embriões humanos produzidos por fertilização in vitro e não utilizados no respectivo procedimento."

Desse enunciado verifica-se que o legislador impôs algumas condições para a realização das pesquisas células-tronco envolvendo embriões humanos. O primeiro elenco de condições é de caráter intrínseco, vale dizer que são pressupostos relativos aos embriões propriamente ditos, a saber: (I) embriões humanos obtidos por fertilização in vitro; (II) embriões inviáveis, não utilizados no procedimento de fertilização; e (III) embriões congelados, há pelo menos 3 (três) anos, na data da publicação da Lei n $n^{\circ} 11.105 / 05$, ou se já congelados nessa mesma data, depois de completarem 3 (três) anos, contados a partir da data de congelamento. Todas essas condições são cumulativas.

No tocante às condições extrínsecas, algumas delas já examinadas, as exigências se limitam aos documentos necessários para a realização dos experimentos: (I) consentimento formal e escrito, dos genitores ${ }^{23}$; (II) apreciação e aprovação do projeto de pesquisas ou terapia

\footnotetext{
${ }^{22} \mathrm{O}$ fenômeno da diferenciação celular é extremamente importante para a compreensão do funcionamento do organismo. Isso porque, como se sabe, as células só podem fazer parte de determinado tecido específico. Se for o pâncreas, a célula não poderá se reproduzir e diferenciar-se em outro tipo que não aquelas propícias a constituir o tecido pancreático. E essa especificidade da célula, repita-se, é fundamental para a constituição dos seres vivos. Afinal de contas, é fácil imaginar as consequências de uma célula responsável pela produção de enzimas, que atuam em nosso sistema digestivo, sendo reproduzida no cérebro, por exemplo: desnecessário dizer que os nossos neurônios seriam destruídos nessa hipótese. Daí a sua importância.

${ }^{23}$ Embora a lei não faça referência, entendemos que esse consentimento para utilização dos embriões deverá ser informado, vale dizer que os genitores deverão estar plenamente informados a respeito da utilização dos embriões, e das consequências desta utilização, antes de consentirem o uso científico dos mesmos. Em outros termos, o consentimento para o experimento científico com seres humanos somente gerará efeitos após explicação completa e pormenorizada sobre a natureza da pesquisa, seus objetivos, métodos, benefícios
} 
com células-tronco embrionárias humanas pelos comitês de ética das instituições de pesquisa e centros de saúde que se dedicam a tais pesquisas ${ }^{24}$.

Mais do que controlar as experimentações com embriões, o legislador resolveu, no Decreto $\mathrm{n}^{\circ} 5591 / 2005$, monitorar a produção dos mesmos, enquanto acondicionados para fertilização ou pesquisas, exigindo, das "instituições que exercem atividades que envolvam congelamento e armazenamento de embriões humanos", as chamadas clínicas de reprodução humana assistida, o cumprimento de uma obrigação de "informar, conforme norma específica que estabelecerá prazos, os dados necessários à identificação dos embriões inviáveis produzidos em seus estabelecimentos e dos embriões congelados disponíveis”.

$\mathrm{Na}$ regulamentação interna das pesquisas com embriões, o legislador nacional tem resistido a "coisificar" os embriões, vendo neles, ao contrário de um simples objeto de experimento, uma entidade que, se ainda não se poderia considerar como um ser humano completo, ao menos um organismo a qual se deva respeitar a busca da viabilidade de tornar-se, dignamente, uma pessoa.

Destarte, nesse contexto, a Lei de Biossegurança, nos seus artigos 24 a 26, estabelece que várias condutas representam crimes, com penalidades que vão de detenção a reclusão.

O artigo 24 da lei define como crime a utilização de embrião humano em desacordo com o artigo $5^{\circ}$ da Lei de Biossegurança, atribuindo, para essa prática, uma pena de detenção de 1 (um) a 3 (três) anos. Isso porque o legislador criminal procura resguardar a intangibilidade do embrião humano, ao punir condutas como "não produzir", "não armazenar" e "não manipular". Contudo, não se aplica, à interdição apontada, a utilização de embriões para produção de células-tronco para fins terapêuticos e de pesquisa ${ }^{25}$.

No artigo 25 proíbe-se a prática de engenharia genética em célula germinal humana, zigoto humano ou embrião humano, sendo que quaisquer desses comportamentos é tido como crime passível de pena de reclusão de 1 a 4 anos. Não se poderá produzir ou manipular moléculas de ADN/ARN recombinante ${ }^{26}$, pois o que o legislador procura proteger é a intangibilidade do patrimônio genético de cada pessoa, de modo a se preservar essa

previstos, potenciais riscos e o incômodo que esta possa acarretar (Resolução CNS 466/21, III.3, letras a, b, c e d).

${ }^{24}$ De acordo com a Resolução CNS 466/21, item VII.2, Comitês de Ética em Pesquisa, os chamados CEP's, são "colegiados interdisciplinares e independentes, de relevância pública, de caráter consultivo, deliberativo e educativo, criados para defender os interesses dos participantes da pesquisa em sua integridade e dignidade e para contribuir no desenvolvimento da pesquisa dentro de padrões éticos".

${ }^{25}$ Lei $11.105 / 2005$, artigo $5^{\circ}$.

${ }^{26}$ Lei $11.105 / 2005$, artigo $3^{\circ}$, inciso IV. 
individualidade. Portanto, a proibição em questão não inclui a engenharia genética em células somáticas.

Já o artigo 26 fala em clonagem, que tem prática restrita. Trata-se de um processo de reprodução assexuada, artificial, baseada em um único material genético, com ou sem utilização de técnicas de engenharia genética. Esse ilícito pode implicar na aplicação de pena de reclusão de 2 (dois) a 5 (cinco) anos. Se no delito do artigo 25 a proteção é da individualidade do patrimônio do material genético de cada um, aqui o que se protege é a individualidade do ser humano enquanto pessoa. Porém, admite-se a clonagem terapêutica, que a lei define como sendo a clonagem para produção de células-tronco embrionárias para fins terapêuticos.

Uma observação é pertinente: enquanto o objeto jurídico penalmente tutelado é, no caso do artigo 24, a utilização do embrião exclusivamente para os fins previstos no $\operatorname{artigo} 5^{\circ}$ da Lei de Biossegurança, na hipótese do artigo 26 o que o legislador pretende proteger é a originalidade que cada ser humano traz em si desde o nascimento, que faz com que nenhum ser existente na face da terra seja exatamente igual ao outro. E isso mesmo considerando as hipóteses de nascimento de clones naturais.

A todas essas exigências previstas pela Lei de Biossegurança e pelo decreto que a regulamenta, acrescente-se, conforme dissemos no início, a necessidade de observância das normas gerais que regulamentam as pesquisas científicas em geral, e os experimentos em genética em particular, consoante o disposto no artigo 63, parágrafo $2^{\circ}$, do Decreto $\mathrm{n}^{\circ}$ $5.591 / 2005^{27}$.

Objetivando fazer prevalecer o princípio da dignidade humana contemplado em inúmeros documentos internacionais, a ONU vem tentando obter um compromisso dos Estados-membros no sentido de se coibir a utilização de embriões para certos tipos de experimentos, principalmente a clonagem reprodutiva de seres humanos, ou de suas partes.

Qualquer que seja o procedimento utilizado, a clonagem terapêutica segue quase o mesmo rito da clonagem reprodutiva. Ambas podem obedecer a processos semelhantes, quase idênticos. Porém, no caso de clonagem terapêutica, a divisão das células destinadas a constituir o embrião é interrompida, após algumas horas, no estágio conhecido como "blastocysto”, para efeito de coleta de células-tronco. Já na hipótese de clonagem reprodutiva não há interrupção da divisão celular. Como o próprio nome indica, o objetivo é a reprodução do objeto da

\footnotetext{
27 "§ 20 Instituições de pesquisa e serviços de saúde que realizem pesquisa ou terapia com células-tronco embrionárias humanas deverão submeter seus projetos à apreciação e aprovação dos respectivos comitês de ética em pesquisa, na forma de resolução do Conselho Nacional de Saúde."
} 
clonagem. Esse processo compreende desde o desenvolvimento do embrião, in vitro, e a sua posterior implantação no útero materno, até o surgimento do feto e seu respectivo nascimento.

Internacionalmente, a construção de limites éticos começa pelo projeto de Convenção das Nações Unidas para Proibição da Clonagem de Seres Humanos ${ }^{28}$, cuja elaboração foi decidida em 2001 pela Assembleia Geral. Neste documento, o que é importante notar é justamente a disposição das nações do globo em proibirem uma ou outra espécie de clonagem de seres humanos. Infelizmente o projeto não saiu do papel, considerando algumas divergências quanto ao âmbito de aplicação da proibição.

Com efeito, um grupo de cerca de 60 países, liderados pela Santa Sé, Estados Unidos, Espanha e Itália, preconizam, no âmbito do projeto, uma proibição de caráter geral, vale dizer a toda espécie de clonagem, que seja ela reprodutiva ou não.

Outro grupo, de aproximadamente 17 países, dentre os quais a Inglaterra e a Bélgica, defendem a ideia de que a proibição não se faça em relação à chamada clonagem terapêutica, devendo a interdição prevalecer unicamente no que diz respeito à clonagem reprodutiva. Enfim, há um terceiro grupo de países, no qual estão incluídos a França e a Alemanha ${ }^{29}$, que adotam uma posição intermediária: condenam a clonagem reprodutiva, mas sustentam que a legalização dos outros tipos de clonagem deve ser deixada ao arbítrio de cada nação que, individualmente, regulamentaria os procedimentos de clonagem permitidos em seu território.

A propósito, vejamos como está a regulamentação da restrição de experimentos com embriões nos outros países.

\section{Limites aos experimentos com embriões nos países estrangeiros}

Em termos de países estrangeiros, Hermannys (2002) nos dá notícia de que algumas nações proíbem, expressa ou implicitamente, a criação de uma categoria especial de "embriões para pesquisa".

No caso da Alemanha, proíbe-se "o intento de fertilizar artificialmente um óvulo, se não é com o fim de gerar uma gravidez na mulher que o originou", sancionando criminalmente a conduta do "responsável pelo desenvolvimento extracorporal de um embrião com outros fins que não a gravidez". Na Noruega, só se permite a realização de fertilização in vitro em face de

\footnotetext{
${ }^{28}$ http://www.un.org/law/cloning/index.html

${ }^{29}$ Essa posição oficial da Alemanha foi adotada embora o Bundestag tivesse votado uma resolução proibindo toda e qualquer forma de clonagem humana, inclusive as não reprodutivas.
} 
uma situação de esterilidade ${ }^{30}$. Entretanto, considerando a riqueza de detalhes, convém nos determos na análise das legislações da França e da Espanha.

Contudo, as situações que mais podem nos trazer lições são a da França (A) e da Espanha (B). Senão vejamos.

\section{a. Experimentação com embriões na França}

Na França, antes de 1992 não havia regulamentação para a pesquisa com embriões. Mas, nesse mesmo ano, quando dos debates parlamentares a respeito do projeto de lei sobre doação e uso de elementos do corpo humano, e reprodução humana assistida, foi apresentada uma emenda ao projeto de lei ${ }^{31}$, com finalidade de regulamentar a pesquisa embrionária e, sobretudo, solucionar o problema dos embriões excedentes.

Por essa emenda, os experimentos em embriões seriam possíveis somente a título excepcional, condicionado ao parecer favorável da Comissão Nacional de Medicina e Biologia da Reprodução Humana. Portanto, além de ter dado a estas pesquisas um caráter excepcional, o projeto propôs também um controle prévio de toda e qualquer iniciativa de pesquisa que versasse sobre experimentos com embriões.

Em complemento à Emenda n ${ }^{\circ} 29$, os deputados franceses apresentaram outra, Emenda $\mathrm{n}^{\circ} 180$, propondo que as clínicas de fertilização assistida autorizadas a realizar experimentos com embriões apresentassem um Relatório Anual com informações a respeito do destino dos embriões que foram objeto de criopreservação e de experimentação. Em outros termos, essa emenda propunha maior transparência para as atividades das clínicas de fertilização assistida, o que permitiria aos poderes públicos realizarem, "a posteriori”, um controle sobre esses estabelecimentos $^{32}$.

Porém, o Senado, através de sua Comissão de Assuntos Sociais, pronunciou-se contrariamente aos projetos de lei apresentados pelos deputados. Fiel ao conservadorismo, o Senado francês opinou pela impossibilidade de se praticar qualquer experimento com embriões. O impasse estava formado em torno do tema. Após um ano e meio de discussões, a Assembleia

\footnotetext{
${ }^{30}$ Pensamos que essa imposição, prevista na lei norueguesa, deveria ser tida como "codition sine qua non" para a realização da fertilização in vitro: uma vez não comprovado o estado de infertilidade, os médicos deveriam se abster de realizar a procriação extracorpórea.

${ }^{31}$ Emenda no $29 / 19992$.

${ }^{32}$ Essa providência foi adotada pelo Decreto 5.591/05 que. E, seu artigo 64, parágrafo $1^{\circ}$, dispôs que "as instituições que exercem atividades que envolvam congelamento e armazenamento de embriões humanos deverão informar, conforme norma específica que estabelecerá prazos, os dados necessários à identificação dos embriões inviáveis produzidos em seus estabelecimentos e dos embriões congelados disponíveis", sendo que a regulamentação a que se refere o parágrafo $1^{\circ}$ caberá ao Ministério da Saúde.
} 
Nacional e o Senado chegaram a um acordo e adotaram a Lei de 29 de julho de 1994, mais conhecida como "Lois de Bioéthique de 1994".

Com efeito, a regra nas Leis de Bioética de 1994, previstas para serem revistas a cada 5 anos, e com a última revisão em 2013, é pela proibição de experimentações com embriões. Contudo, para não condenar a pesquisa francesa ao sucateamento, os parlamentares acabaram por prever uma exceção a esse princípio. Assim é que o artigo L 152-7, do Código de Saúde Pública, estabelece que "a título excepcional, o homem e a mulher formando um casal podem permitir que sejam realizados estudos em seus embriões". Mas convém precisar que essa exceção está circunscrita a certos limites, tais como (1) a necessidade de que os estudos tenham "uma finalidade médica”, e (2) a obrigação de evitar que esses estudos prejudiquem o embrião.

Quanto à obrigação de não prejudicar o embrião, a doutrina entende que essa exigência deve ser interpretada com certa parcimônia, eis que necessário se faz conjugá-la com a permissão para se descartar os embriões excedentes. Em outras palavras, se não se pune quem simplesmente destrói um embrião excedente, porque é permitido fazê-lo, então qual a justificativa para uma solução diferente em se tratando de embriões usados em estudo? $\mathrm{Na}$ verdade, o que se pretende coibir é a destruição voluntária dos embriões usados em pesquisa.

A legislação francesa também não prevê sanção para a falta do parecer da Comissão Nacional de Medicina e Biologia da Reprodução. Alguns autores afirmam que a sanção para a falta do parecer da Comissão seria aquela prevista no artigo L 184-6 do Código de Saúde Pública, ou seja, a perda da autorização de realizar as atividades que estariam autorizadas pelo parecer. Mas mesmo essa solução não parece satisfazer os críticos das Leis de Bioética de 1994, pois, no caso desta sanção, a clínica continuaria a poder realizar reprodução assistida.

Em nome da transparência, as leis francesas também estabelecem que esses estudos devam exigir um parecer prévio da Comissão Nacional de Medicina e Biologia da Reprodução Humana, que publicará anualmente uma lista das clínicas de fertilização assistida e laboratórios onde estas pesquisas estão se desenvolvendo, bem como o objeto das mesmas.

\section{b. Experimentação com embriões na Espanha}

$\mathrm{Na}$ Espanha, em 1988 foi votada pelo parlamento a Lei $\mathrm{n}^{\circ} 35 / 1988$, que disciplina as técnicas de reprodução humana assistida e permite a realização de experimentos com embriões, desde que estes tenham sido obtidos por técnicas de reprodução humana assistida, (I) sejam inviáveis e (II) que não façam mais parte de um projeto familiar. Portanto, a utilização destes 
embriões pressupõe: (a) a obtenção por técnicas de Reprodução Humana Assistida, (b) a inviabilidade dos mesmos, (c) autorização do casal gerador dos embriões.

Mas a aprovação desta lei provocou sérias contestações na Espanha, tendo, inclusive, sido arguida a sua inconstitucionalidade, considerando que a lei que regulamente este tipo de experimento, ao fazê-lo, viola o direito fundamental à vida previsto no artigo 15 da Constituição da Espanha.

Sobre a inconstitucionalidade da Lei $\mathrm{n}^{\circ} 35 / 1988$, que disciplina as técnicas de reprodução humana assistida e permite a realização de experimentos com embriões inviáveis na Espanha, o Tribunal Constitucional ${ }^{33}$ entendeu que a Lei ${ }^{\circ}$ 35/1988 não estava em desacordo com a Constituição, a qual contempla a tutela da vida pelos poderes públicos ${ }^{34}$. Isso porque, de acordo com essa mesma Corte de Justiça, os embriões e fetos não viáveis não estão amparados por tal dever imposto aos poderes públicos, pois estes só têm o dever de garantir a vida, ou a sua viabilidade.

Assim, se esta incumbência do Estado diz respeito à preservação da vida, e se tantos os embriões quanto os fetos passíveis de servirem para experimentos científicos são considerados inviáveis para efeito de se tornarem ser humano, o Tribunal Constitucional declarou conforme a Constituição a Lei no 35/88 que autoriza o uso, daqueles, como objeto de experimento.

Se o Tribunal Constitucional da Espanha vem, desde há muito, consagrando, e reiterando ${ }^{35}$, a proteção jurídica dos nascituros dentro do contexto da proteção dos direitos fundamentais da pessoa humana, o fato é que essa jurisprudência não se aplica ao caso dos embriões e fetos inviáveis.

Isso porque, segundo essa mesma Corte de Justiça, o legislador que confeccionou a Lei $n^{\circ} 35 / 88$ partiu do pressuposto fundamental de que esses embriões e fetos, passíveis de serem usados em experimentos, são inviáveis. Viável, diz o Tribunal Constitucional, é o adjetivo cujo significado o dicionário descreve como "capaz de viver". Aplicado ao embrião e ao feto humano, sua caracterização como não viável faz referência concretamente a sua incapacidade de desenvolver-se até dar lugar a um ser humano, a uma pessoa fundamental passível da tutela constitucional prevista no artigo 10 da Carta Constitucional Espanhola. São, assim, por definição, os embriões e fetos humanos abortados.

Além disso, a jurisdição constitucional espanhola afirmou que a Lei ${ }^{\circ} 35 / 88$ parte de uma premissa que, por definição, tal norma não contempla a figura dos embriões e fetos viáveis,

\footnotetext{
${ }^{33}$ O Tribunal Constitucional da Espanha é designado pela sigla STC (Superior Tribunal Constitucional).

${ }^{34}$ STC 212/96.

${ }^{35}$ STC $116 / 99$.
} 
estes o objeto da tutela constitucional. Por conseguinte, não cabe a tentativa de equipará-los aos nascituros, pois estes têm viabilidade de viver, o que não é o caso daqueles, que nunca nascerão: daí o emprego do vocábulo "inviáveis".

Aliás, o Tribunal Constitucional cita um precedente de sua própria jurisdição ${ }^{36}$, no qual ficou bem claro o que se deva entender por nascituro digno da tutela constitucional: aquele que vai nascer, no sentido de levar uma vida própria, independente da mãe.

Em definitivo, a declaração de conformidade da Lei no 35/88 à Constituição, feita pela Corte Constitucional da Espanha, implica no reconhecimento da constitucionalidade das intervenções em pré-embrião, embriões e fetos, com finalidade terapêutica, bem como da experimentação com gametas, pré-embriões e embriões inviáveis, pois toda esta matéria não integra o conteúdo dos direitos fundamentais previstos no artigo 15 da Constituição da Espanha.

\section{Conclusão}

De todo o exposto, concluímos que não só o Brasil, mas vários países estrangeiros evoluíram no sentido de travestirem as regras de deontologia, que tratam das pesquisas com seres humanos, inclusive embriões, em normas de direito positivo, no sentido de dar maior efetividade à proteção da vida e da saúde das pessoas submetidas a experimentos, e isso qualquer que seja a fase de desenvolvimento delas, mesmo enquanto embriões, de modo que um equilíbrio foi encontrado entre a necessidade de se proceder às pesquisas, e a de preservar a dignidade da vida em embriões que, se outrora eram "coisificados" através de um simples descarte, hoje têm a sua destinação engrandecida em prol da humanidade.

\section{Referências}

BERLINGER, G.; GARRAFA, V. O Mercado humano. Brasília: UnB, 2001. 252 p.

BERLINGER, G.; GARRAFA, V. Limites al interés colectivo en el campo de la genética clínica: el conflicto entre as exigencias de salud pública y la salvaguarda de la dignidad humana. In: DURÁN, A.; RIECHMANN, J. (coord.). Genes en el Laboratorio y en la Fábrica. Madrid: Trotta, 1998. p. 81-96.

FAGUNDES JUNIOR, J. C. P. Limites da ciência e o respeito à dignidade humana. In: SANTOS, M. C. C. L. Biodireito: ciência da vida, os novos desafios. São Paulo: Rev. Tribunais, 2001. p. 267-281.

FALLA, G. El derecho a la intimidad y el uso de la información genética. In: Derecho Ante el Proyecto Genoma Humano. Bilbao: Fundación BBVA, 1994. v. 1.

${ }^{36}$ STC 53/1985. 
FEMENÍA LOPEZ, P. J. Limites jurídicos a la alteración del patrimonio genético de los seres humanos (Parte II). Rev. Derecho y Gen. Hum., n. 10, 1999. p. 91-105.

GARRAFA, V.; BERLINGER, G. O Mercado humano. Brasília: UnB, 2001. 252 p.

JACOB, F. A Lógica da vida: uma história da hereditariedade. Trad. SOUZA, A. L. Rio de Janeiro: Ed. Graal, 1983.

LENOIR, N. e MATHIEU, B., Les Normes Internationales de La Bioétique Paris: PUF, 2004, $118 \mathrm{p}$.

MATHIEU, B., e LENOIR, N., Les normes internationales de la bioétique. 2. ed. Paris: PUF, 2004. $118 \mathrm{p}$.

MAYR, E. O desenvolvimento do pensamento biológico: diversidade, evolução e herança. Trad. I. Martinazzo. Brasília: Ed. UnB, Brasília, DF, 1998. 1107 p.

MIR, J. L. G. Genômica. São Paulo: Atheneu, 2004. 1212 p.

MORÁN, N. M. Persona, dignidad humana em investigaciones médicas. In: ROMEO CASABONA, C. M.; MARTÍNEZ MORÁN, N. (coord.). Biotecnologia, derecho y dignidad humana. Granada: Comares, 2003. p. 03-44.

NYS, H. Experimentação com Embriões. In: ROMEO, Carlos Maria Romeo (org.). Biotecnologia, direito e bioética. Belo Horizonte: Casabona, Ed. Del Rey e PUC Minas, 2002. p.179.

RIDLEY, M. O que nos faz humanos. Trad. R. Vinagre. Rio de Janeiro: Record, 2004. 416 p.

SANTOS, M. C. C. L. Biodireito: ciência da vida, os novos desafios. São Paulo: Revista dos Tribunais, 2001. $450 \mathrm{p}$.

SANTOS, M. C. C. L. O Equilíbrio do Pêndulo: a Bioética e a Lei. Implicações MédicoLegais. São Paulo: Ícone, 1998. 65 p.

SILVA, R. P. Biodireito: a nova fronteira dos direitos humanos. São Paulo: Ed. Ltr, 2003. 222 p. 